\title{
IMPLEMENTATION OF CORPORATE SOCIAL RESPONSIBILITY BY PT ASIA FORESTAMA RAYA IN RUMBAI PESISIR DISTRICT OF PEKANBARU CITY BASED ON REGIONAL REGULATION OF RIAU PROVINCE \#6 OF 2012
}

\author{
Suhendro*, Associate Professor \\ Utama Andrew Shandy, Lecturer \\ Faculty of Law, University of Lancang Kuning, Indonesia \\ ${ }^{\star}$ E-mail: suhendroadhukum@gmail.com
}

\begin{abstract}
Article 11 of Regional Regulation of Riau Province Number 6 of 2012 stated that the corporate social responsibility could be implemented in the fields of education, health, infrastructure, sports and culture, social and religion, environmental preservation, community economic enterprises, empowerment of indigenous peoples, as well as other fields that bring significant impacts on improving the quality of society. This research focuses on two problems namely(1) How is the implementation of corporate social responsibility of PT Asia Forestama Raya in improving the economy of the community based on Regional Regulation of Riau Province Number 6 of 2012? (2) What are the obstacles in the implementation and how are the efforts to overcome these obstacles? This research employed socio-legal research method. The results of this research indicated that PT Asia Forestama Raya did not implement corporate social responsibility to empower the economy of the community in the District of Rumbai Pesisir, Pekanbaru City. Based on the company's point of view, the obstacles in the implementation were the unstable financial condition of PT Asia Forestama Raya which made them fail to implement a community economic empowerment program for three years. From the point of view of the community, the obstacle was the lack of knowledge regarding Regional Regulation of Riau Province Number 6 of 2012. Further, the government had not implemented adequate supervision of the corporate social responsibility implementation by PT Asia Forestama Raya. Efforts to overcome these obstacles were based on Article 32 of Regional Regulation of Riau Province Number 6 of 2012 which stated that if PT Asia Forestama Raya did not implement corporate social responsibility, then the company may be subject to administrative sanctions in the form of written warnings from the Pekanbaru City Government as well as restrictions on business activities, suspension of business licenses, and revocation of business licenses.
\end{abstract}

\section{KEY WORDS}

Corporate social responsibility, implementation, society, public service.

The existence of companies has become a dominant business institution. Companies have influenced national economic development. Their activities have created employment, provided products and services needed for people's lives, increased sustainable economic development, improved national technological capacity and capability, and actualized community welfare in a competitive economic system.

Various regulations related to institutional and business activities of the companies have been implemented. In principle, a company is a private institution established based on capital with the primary goal of making a profit. Since their goal is to make profit, companies may conduct business activities without regard to moral values and business ethics, so that the company's operations cause various social problems, such as social inequality, causing uncomfortable environment, wasteful use of natural resources, inequality of position between producers and consumers, and the inequality in bargaining positions between companies and employees. In fact, without realizing it, the company has denigrated human dignity and the environment.

On the other hand, the company and the community are increasingly closer in terms of social interactions. The company has influenced all lines of the community life. The 
company, apart from being a business institution, is also a part of the citizens (corporate citizenship) who is directly involved with the dynamics of society. The sustainability of the company's business is also greatly dependent on economic conditions and the quality of the community life. Companies must not only seek profit, but also participate in environmental sustainability and care for the social problems faced by the community.

In general, the principles that apply in good business activities cannot be separated from our lives as human beings. The principles are closely related to the value system adopted by the community. The principles in business ethics include the principle of autonomy, the principle of honesty, the principle of doing good (beneficence) and not doing evil (non-maleficence), the principle of justice, and the principle of respect for oneself (Ridwan Khairandy, 2009).

Social responsibility is basically a derivation of business ethics. The business ethics arises from the existence of business interactions between people who complement each other's needs as a result of the complexity of unlimited and growing human needs. Business ethics can bridge the interests between the needs of the company and the social community, both those directly and indirectly affected by the company's operations (Fahmi, 2015).

From the perspective of business law, there are at least two responsibilities in business ethics, namely legal responsibility which includes civil liability and crime liability, as well as social responsibility which is built on the foundation of moral norms prevailing in society. In the 1990s, corporate social responsibility became an idea that caught the attention of various groups, including academics, non-governmental organizations, and business people. Implementation of corporate social responsibility by the company means that the company is not only a business entity trying to seek profit alone, but also an integral part of the economic, social, and environmental conditions in which the company operates (Ridwan Khairandy, 2009).

PT Asia Forestama Raya is a forest product processing factory for wood industry raw material. PT Asia Forestama Raya began operating in Pekanbaru City in 1986 under the name PT Rantau Jaya Sakti, located in Rumbai Pesisir District. Initially the company stood on an empty forest on the banks of the Siak River in Pekanbaru City countryside. However, along with the development and progress of Pekanbaru City as the capital of Riau Province, Rumbai Pesisir District turned into a densely populated area.

In Article 74 of Law Number 40 Year 2007 concerning Limited Liability Companies, it is emphasized that companies which carry out their business activities in the fields and/or related to natural resources are required to carry out corporate social responsibility. This regulation aims to continue to create a harmonious, balanced and compatible company relationship with the environment, values, norms and culture of the local community.

The implementation of Regional Regulation of Riau Province No. 6 of 2012 concerning Corporate Social Responsibility in Riau Province further strengthens the legal basis for implementing corporate social responsibility for companies operating in the Riau Province region. Article 10 of Regional Regulation of Riau Province Number 6 of 2012 concerning Corporate Social Responsibility in Riau Province states that corporate social responsibility programs can take the form of community empowerment and/or partnerships and environmental development and/or investment and/or charity/donations, and/or promotion. Furthermore, Article 11 of the regional regulation also states that the corporate social responsibility can be carried out in the fields of education, health, infrastructure, sports and culture, social and religion, environmental preservation, community economic enterprises, indigenous people's empowerment, and other fields that actually have an impact in improving the quality of society.

From preliminary observations made in the Rumbai Pesisir District of Pekanbaru City, researchers obtained information from the public that the community barely experienced corporate social responsibility program, especially community economic empowerment, carried out by PT Asia Forestama Raya.

Based on the background of the problem described above, the researchers are interested in conducting a study entitled "Implementation of Corporate Social Responsibility 
by PT. Asia Forestama Raya in Rumbai Pesisir District Pekanbaru City Based on Regional Regulation of Riau Province Number 6 of 2012".

\section{LITERATURE REVIEW}

Experts have written various literatures about company law discussing corporate social responsibility. One of them is Ridwan Khairandy's book entitled "Perseroan Terbatas; Doktrin, Peraturan Perundang-undangan, and Yurisprudensi" (Limited Liability Companies: Doctrine, Statutory Regulations and Jurisprudence). In his book, Ridwan Khairandy discusses corporate social responsibility from the beginning of the concept of corporate social responsibility, the meaning and scope of corporate social responsibility, as well as business ethics and social responsibility in corporate activities (Ridwan Khairandy, 2009). In addition, Habib Adjie in the book "Status Badan Hukum, Prinsip-prinsip and Tanggung Jawab Sosial Perseroan Terbatas (Status of Legal Entity, Principles and Social Responsibility of Limited Liability Companies) also discusses corporate social responsibility starting from the meaning of corporate social responsibility, the scope of corporate social responsibility, and the relationship of corporate social responsibility with business ethics (Habib Ajie, 2008). However, in the two books there is no discussion about the implementation of corporate social responsibility in regards of the empowerment of the people's economy.

The implementation of corporate social responsibility related to community economic empowerment is discussed by Hendrik Budi Untung in his book "Corporate Social Responsibility". In this book, Hendrik Budi Untung explains the implementation of corporate social responsibility by PT Kaltim Prima Coal for the people of Rantau Pulung District in East Kutai Regency. He argues that the corporate social responsibility program run by PT Kaltim Prima Coal was able to improve the economy and welfare of the fruit farmers (Hendrik Budi Untung, 2009).

In Respublica Legal Journal Volume 7 Number 1 of 2007, Zulfikar Jayakusuma wrote an article entitled "Tanggung Jawab Sosial Perusahaan Transnasional Pertambangan Minyak terhadap Masyarakat Lokal (Perspektif Hak Asasi Manusia)" (Social Responsibility of Transnational Oil Mining Companies towards Local Communities (Human Rights Perspective)). He argues that integrating corporate social responsibility with human rights is a parameter to measure the implementation of corporate social responsibility towards local communities (Zulfikar Jayakusuma, 2007). In the same journal, Yetti wrote "Tanggung Jawab Perusahaan terhadap Sosial and Lingkungan Berdasarkan Undang-Undang Nomor 40 Tahun 2007 tentang Perseroan Terbatas" (Corporate Social and Environmental Responsibility Under Law Number 40 Year 2007 concerning Limited Liability Companies). Yetti argues that the corporate social responsibility program as a form of corporate social solidarity is not only useful for the community, but also for shaping the company's image if it is implemented with the right publications (Yetti, 2007).

In the Yustisia Journal of Law Edition 77 of 2009, Sentosa Sembiring wrote "Tanggung Jawab Sosial and Lingkungan (Corporate Social and Environment Responsibilities) dalam Perspektif Hukum Perusahaan" (Corporate Social and Environmental Responsibility in the Corporate Law Perspective). Semibiring argues that the substance of the existence of corporate social responsibility is to strengthen the sustainability of the company by establishing cooperation with stakeholders through community development programs (Sentosa Sembiring, 2009).

In Respublica Legal Journal Volume 8 Number 2 of 2009, Ferdi wrote "Aspek Hukum Internasional dalam Pengaturan Tanggung Jawab Sosial Perusahaan (Corporate Social Responsibility)" (Aspects of International Law in the Arrangement of Corporate Social Responsibility). Ferdi argues that corporate social responsibility is motivated by the concept of sustainable development which was formulated in international conference in Stockholm in 1982. The sustainability of a company is not only determined by the level of profits, but also corporate social responsibility (Ferdi, 2009). 
In Respublica Legal Journal Volume 9 Number 2 of 2010, Budi Santoso wrote "International CSR Standards dari Sudut Pandang Hukum Internasional". Santoso argues that a company's business activities can have impact on others, the community, and the environment in which the company operates (Budi Santoso, 2010).

In Respublica Legal Journal Volume 11 Number 1 of 2011, Firdaus wrote under the title "Corporate Social Responsibility dalam Hak Asasi Manusia, Studi terhadap Pemenuhan Hak Ekonomi Sosial Masyarakat Lokal oleh Perusahaan Perkebunan Kelapa Sawit". Firdaus argues that management of natural resources by companies without regard to human rights can harm the economic and social rights of local communities. Corporate social responsibility related to human rights is essential so that natural resource management can fulfill basic principles, namely realizing prosperity for the community (Firdaus, 2011). In the same journal, Yetti wrote under the title "Implikasi Corporate Social Responsibility terhadap Aplikasi Undang-Undang Nomor 5 Tahun 1999" (Implications of Corporate Social Responsibility for the Application of Law Number 5 of 1999). Yetti argues that the implementation of corporate social responsibility is no longer considered as a cost, but as a corporate investment, since the company and the community are highly interdependent (Yetti, 2011).

In a book entitled "Pergeseran Tanggung Jawab Sosial Perseroan, Dari Tanggung Jawab Moral ke Tanggung Jawab Hukum" written in 2015, Fahmi as the author explained that business ethics is the basis of corporate social responsibility. Regarding the implementation of corporate social responsibility towards community economic empowerment, Fahmi only explains the implementation of corporate social responsibility by companies engaged in the management of Industrial Plantation Forests ( $\mathrm{HTI}$ ) in Riau Province (Fahmi, 2015).

Suhendro, Miftahul Haq, and Andrew Shandy Utama in a study funded by APBF Law UNILAK in 2018 study "Pelaksanaan Corporate Social Responsibility PT Riau Crumb Rubber Factory terhadap Masyarakat Kecamatan Rumbai Pesisir Berdasarkan Peraturan Daerah Provinsi Riau Nomor 6 Tahun 2012". They argue that PT Riau Crumb Rubber Factory did not carry out corporate social responsibility to the people of Rumbai Pesisir District of Pekanbaru City as regulated in Regional Regulation of Riau Province No. 6 of 2012 concerning Corporate Social Responsibility in Riau Province. Obstacles in its implementation from the company side are the PT Riau Crumb Rubber Factory only had a limited budget for corporate social responsibility funds which was not able to meet all the needs of the community, while from the community side was the lack of legal knowledge in the District of Rumbai Pesisir Pekanbaru City regarding Regional Regulation of Riau Province Number 6 of 2012 concerning Corporate Social Responsibility in Riau Province. As efforts to overcome these obstacles, people of Rumbai Pesisir Pekanbaru City can express their aspirations to the Commission IV of the City of Pekanbaru (DPRD) if PT Riau Crumb Rubber Factory does not carry out corporate social responsibility, so that the company is recommended to receive sanctions from the Pekanbaru City Government, namely administrative sanctions ranging from written warnings from the government to the suspension of company operational permits.

In addition, Suhendro, Miftahul Haq, and Andrew Shandy Utama also suggested that PT Riau Crumb Rubber Factory should carry out corporate social responsibility to the people of Rumbai Pesisir District of Pekanbaru City as regulated in Regional Regulation of Riau Province Number 6 of 2012 concerning Corporate Social Responsibility in Riau Province, without waiting for the people of the Rumbai Pesisir District of Pekanbaru City to submit proposals for assistance. PT Riau Crumb Rubber Factory should formally report its corporate social responsibility programs for the community to the government, at least to Lurah Meranti Pandak. PT Riau Crumb Rubber Factory should also work closely with the government and universities to provide legal knowledge to the people of Rumbai Pesisir Pekanbaru City regarding Law Number 40 of 2007 concerning Limited Liability Companies and Regional Regulation of Riau Province Number 6 of 2012 concerning Social Responsibility Companies in Riau Province, especially regarding corporate social responsibility, to avoid misunderstandings between the company and the community. 
Based on the literature review as described above, no discussion was found regarding the implementation of corporate social responsibility by PT Asia Forestama Raya in the Rumbai Pesisir District of Pekanbaru City based on Regional Regulation of Riau Province Number 6 of 2012 concerning Corporate Social Responsibility in Riau Province. Even if there is a discussion about the implementation of corporate social responsibility for the people who live around the company location, the research is conducted in a different location from this research.

Research Objectives:

- To explain the implementation of PT Asia Forestama Raya's corporate social responsibility in the Rumbai Pesisir District of Pekanbaru City based on Riau Province Regulation Number 6 of 2012 concerning Corporate Social Responsibility in Riau Province;

- To explain the obstacles in the implementation of PT Asia Forestama Raya's corporate social responsibility in the Rumbai Pesisir District of Pekanbaru City based on Riau Province Regulation Number 6 of 2012 concerning Corporate Social Responsibility in Riau Province;

- To explain efforts to overcome the obstacles in the implementation of PT Asia Forestama Raya's corporate social responsibility in the Rumbai Pesisir District of Pekanbaru City based on Riau Province Regulation Number 6 of 2012 concerning Corporate Social Responsibility in Riau Province.

Research Benefits:

- To broaden the knowledge of the researchers and become a reference for the future researchers who study the implementation of corporate social responsibility for the empowerment of the people's economy;

- To enrich the knowledge in the academic world, especially in the field of legal science;

- To be a reference for the Pekanbaru City Government in making policies.

\section{METHODS OF RESEARCH}

This research is a sociological legal research using the approach of positive law implementation to the community. The sociological legal research is useful to find out how the law is implemented, including the process of law enforcement. It is because sociological legal research can reveal the problems behind the implementation and enforcement of the law (Amiruddin and Zainal Asikin, 2012).

This research was conducted in the Rumbai Pesisir District of Pekanbaru City. This location was chosen because from the initial observations made in the Rumbai Pesisir District of Pekanbaru City, researchers obtained information from the community that they barely received corporate social responsibility program run by PT Asia Forestama Raya, especially programs related to people's economy empowerment. follows:

The population is the whole object to be studied. The population in this study is as

- Chairman of the Commission IV of the Regional Representative Council (DPRD) of Pekanbaru City, 1 person;

- Head of Rumbai PesisirDistrict, Pekanbaru City, 1 person;

- The manager of PT Asia Forestama Raya, 1 person;

- Representatives of community leaders in the Rumbai Pesisir District of Pekanbaru City, 10 people.

The sample is parts of the population used as respondents in the study. The sample in this study is as follows:

- Chairman of the Commission IV of the Regional Representative Council (DPRD) of Pekanbaru City, 1 person;

- Head of Rumbai Pesisir District, Pekanbaru City, 1 person;

- The manager of PT Asia Forestama Raya, 1 person; 
- Representative of community leaders in the Rumbai Pesisir District of Pekanbaru City, 1 person.

Table 1 - Population and Sample

\begin{tabular}{|c|l|c|c|c|}
\hline No. & \multicolumn{1}{|c|}{ Type } & Population & Sample & Percentage \\
\hline 1 & $\begin{array}{l}\text { Chairman of the Commission IV of the Regional Representative } \\
\text { Council (DPRD) of Pekanbaru City }\end{array}$ & 1 & 1 & $100 \%$ \\
\hline 2 & Head of Rumbai Pesisir District, Pekanbaru City & 1 & 1 & $100 \%$ \\
\hline 3 & The manager of PT Asia Forestama Raya & 1 & 1 & $100 \%$ \\
\hline 4 & $\begin{array}{l}\text { Representative of community leaders in the Rumbai Pesisir District of } \\
\text { Pekanbaru City }\end{array}$ & 10 & 3 & $30 \%$ \\
\hline \multicolumn{2}{|c|}{ Total } & 10 & 5 & $50 \%$ \\
\hline
\end{tabular}

Source: Primary Data, 2018.

Data sources used in this study are as follows:

- Primary data, i.e. data obtained directly from observations and interviews at the research location;

- Secondary data, i.e. data obtained from scientific journals, legal literature, and legislation through literature studies;

- Tertiary data, which is data that functions to support primary data and secondary data.

Data collection techniques used in this study are as follows:

- Observation, which is a technique of collecting data by direct observation at the research location, namely the people of Rumbai Pesisir, Pekanbaru City;

- Interview, which is a technique to collect data by asking structured questions about the implementation of PT Asia Forestama Raya's corporate social responsibility to the respondents;

- Literature study, which is a technique to collect secondary data from scientific journals, legal literature, and legislation relevant to this research.

The data analysis technique used in this study is qualitative analysis. Data that has been analyzed are then concluded using the deductive method, which is drawing conclusions from general matters to specific matters.

\section{RESULTS AND DISCUSSION}

Implementation of Corporate Social Responsibility by PT. Asia Forestama Raya in Rumbai Pesisir District Pekanbaru City Based on Regional Regulation of Riau Province Number 6 of 2012. PT Asia Forestama Raya is a forest products processing factory for wood industry raw materials. PT Asia Forestama Raya began operating in Pekanbaru City in 1986 under the name PT Rantau Jaya Sakti, located in Rumbai Pesisir District. Initially the company stood on an empty forest land on the banks of the Siak River on Pekanbaru City countryside. However, along with the development and progress of the City of Pekanbaru as the capital of Riau Province, Rumbai Pesisir District has turned into a densely populated area.

A company's business activities can have an impact on other people, the community, and the environment in which the company operates (Budi Santoso, 2010: 216).

Pursuant to Article 74 Paragraph (1) of Law Number 40 Year 2007 concerning Limited Liability Companies, companies that carry out their business activities in the field of natural resources and/or fields related to natural resources are required to carry out corporate social responsibility. From the results of research conducted in the Rumbai Pesisir District of Pekanbaru City it is known that PT Asia Forestama Raya does not carry out corporate social responsibility to the community, especially empowering the community's economy. Corporate social responsibility is a legal obligation that must be implemented by each company in order to create a good relationship between the company and the community, especially with the people who live around the company. 
In 2017, PT Riau Crumb Rubber Factory also did not carry out corporate social responsibility to the community in Rumbai District, Pekanbaru City, but there were no strict sanctions from the Pekanbaru City Government to the company (Andrew Shandy Utama \& Rizana, 2017: 185).

Interview with Public Relations of PT Asia Forestama Raya, Anggiat Simamora, found that PT Asia Forestama Raya had several corporate social responsibility programs that had been implemented in the Rumbai Pesisir District of Pekanbaru City, as follows:

- In the field of education, PT Asia Forestama Raya routinely accepts students and college students in internships, field practices, and thesis research;

- In the field of health, PT Asia Forestama Raya has a health clinic for its employees and the clinic is open to the public for the people of Rumbai Pesisir District, Pekanbaru City who live around the company;

- In the field of infrastructure, PT Asia Forestama Raya has cemented the access to the main road to the company, which is also a public road for the people of Rumbai Pesisir, Pekanbaru City, who live around the company;

- In the field of sports and culture, PT Asia Forestama Raya routinely assists sports and cultural activities every year at the Republic of Indonesia's Independence Day celebrations on August 17, which are held by the people of Rumbai Pesisir District, Pekanbaru City who live around the company;

- In the social and religious fields, PT Asia Forestama Raya once helped with the cost of renovating the Baitul Hamdi Mosque located in Limbungan Sub-District, Rumbai Pesisir District, Pekanbaru City;

- In the field of community economic business, PT Asia Forestama Raya has provided land located in the Limbungan Village, Rumbai Pesisir District for community management to become a traditional market.

From the results of the interview above, it is known that PT Asia Forestama Raya has actually carried out corporate social responsibility for community economic empowerment. About ten years ago the company provided a piece of land located in Limbungan, Rumbai Pesisir District for the community to manage into a traditional market and it is still in operation (Andrew Shandy Utama, Rizana, \& Tri Anggara Putra, 2019).

The Integrated Farming System program and the MSME program which is a corporate social responsibility of PT Riau Andalan Pulp and Paper in Pelalawan Regency in 2018 have had an impact on improving the community's economy (Andrew Shandy Utama, 2018).

It can be understood that the success of an area in improving the welfare of its people can be realized if all components of the community are involved, including actual participation from companies operating in the area (Andrew Shandy Utama, 2018).

The implementation of corporate social responsibility is able to strengthen the relationship between the company and the community because the corporate social responsibility program is a real effort by the company to improve the welfare of the community. The implementation of corporate social responsibility has an impact on the community in terms of improving the quality of their welfare, both in the social, economic, educational, and environmental fields, such as access to transportation and job vacancies. Therefore, in the context of accelerating regional development, a joint commitment between local government programs and corporate social responsibility programs should be realized to improve the welfare of the community (Siska Sukmawaty, 2017:216).

Obstacles in Implementation of Corporate Social Responsibility by PT. Asia Forestama Raya in Rumbai Pesisir District Pekanbaru City Based on Regional Regulation of Riau Province Number 6 of 2012. Based on the results of interviews with Public Relations of PT Asia Forestama Raya, Anggiat Simamora, it was explained that PT Asia Forestama Raya had carried out corporate social responsibility to the people of the Rumbai Pesisir District of Pekanbaru City where the company was located in accordance with Article 10 and Article 11 of the Regional Regulation of Riau Province Number 6 of 2012 concerning Corporate Social Responsibility in Riau Province, but the implementation of corporate social responsibility is only carried out to people who live around the company area in Limbungan. 
PT Asia Forestama Raya's public relations officer, Anggiat Simamora, also explained that PT Asia Forestama Raya actually wanted to carry out corporate social responsibility to empower the economy of the community not only to the people who lived around the area of the company, but to the people of Rumbai Pesisir Pekanbaru City in general. However, the company's financial condition is currently unstable, so the community economic empowerment program had not been implemented for three years. This is due to the decreasing amount of supply of wood from forest products. In the past ten years, PT Asia Forestama Raya has no longer obtained wood supply from Riau Province, but from Kalimantan Island, which requires more expensive transportation costs.

Corporate social responsibility is an obligation that must be carried out by PT Asia Forestama Raya to the people of Rumbai Pesisir District, Pekanbaru City, even though the company's financial condition is currently unstable. In fact, the corporate social responsibility should no longer be considered as a cost, but as a corporate investment because the company and the community have high interdependence (Yetti, 2011: 40-41).

Based on interviews with community leaders in the Rumbai Pesisir District of Pekanbaru City, Ali Hanafia, it was explained that the public did not know Law Number 25 of 2007 concerning Investment, Law Number 40 of 2007 concerning Limited Liability Companies, and Regional Regulation of Riau Province Number 6 Year 2012 regarding Corporate Social Responsibility in Riau Province, which confirms that corporate social responsibility is an obligation that must be carried out by PT Asia Forestama Raya. So far, the community has assumed that corporate social responsibility is voluntary assistance from the company for the people who need it.

The substance of the existence of corporate social responsibility is to strengthen the sustainability of a company in an area by establishing cooperation with stakeholders facilitated by the company through community empowerment programs (Suparman, 2013: 80). Based on Article 8 of Regional Regulation of Riau Province No. 6 of 2012 concerning Corporate Social Responsibility in Riau Province, it is emphasized that the company is obliged to establish commitments that corporate social responsibility programs are an inseparable part of management policies and company development programs in company regulations.

Based on Article 28 of Regional Regulation of Riau Province No. 6 of 2012 concerning Corporate Social Responsibility in Riau Province, it is stated that each company must provide a report on the implementation of corporate social responsibility at least once a year to the local government. The corporate social responsibility program as a form of corporate social solidarity is not only useful for the community, but is also useful for shaping the company's image if it is accompanied with the right publications (Yetti, 2007: 116).

Efforts to Overcome Obstacles in Implementation of Corporate Social Responsibility by PT. Asia Forestama Raya in Rumbai Pesisir District Pekanbaru City Based on Regional Regulation of Riau Province Number 6 of 2012. Law No. 25/2007 concerning Investment and Law No. 40/2007 concerning Limited Liability Companies emphasize that corporate social responsibility is an obligation that must be carried out by companies to the public. Since it is an obligation that must be carried out by the company, there should be strict sanctions for the companies that do not carry out corporate social responsibility to the community, especially people who live around the area of the company.

Based on Article 74 Paragraph (3) of Law Number 40 Year 2007 concerning Limited Liability Companies, it is stated that companies which do not carry out social and environmental responsibility are subject to sanctions in accordance with statutory provisions. This means that sanctions against companies that do not carry out corporate social responsibility are stipulated in another law, namely Law Number 25 of 2007 concerning Investment. Pursuant to Article 34 of Law Number 25 Year 2007 concerning Investment, it is affirmed that companies which do not fulfill their obligations in carrying out corporate social responsibility may be subjected to administrative sanctions by the authorized agency or institution in the form of: written warning; restrictions on business activities; freezing of business activities and/or investment facilities; revocation of business activities and/or investment facilities. 
Mandatory legal policies on corporate social responsibility in Indonesia accompanied by sanctions are actually appropriate measures. Changes in the legal paradigm regarding human rights that make companies as caretakers of eco-social rights is a strong supporting factor to the model of legal policy regarding corporate social responsibility in Indonesia (Sefriani and Sri Wartini, 2017: 25-26).

Based on the results of interviews with the Deputy Chairperson of Commission IV of the Pekanbaru City Regional Representative Council (DPRD), Wan Agusti, it was explained that the people of the Rumbai Pesisir District of Pekanbaru City could raise their concerns to the Commission IV of the Pekanbaru City DPRD if PT Asia Forestama Raya did not carry out corporate social responsibility to community, so that the company will be recommended to receive strict sanctions from the Pekanbaru City Government.

Based on Article 32 of the Regional Regulation of Riau Province No. 6 of 2012 concerning Corporate Social Responsibility in Riau Province, it is stated that companies which do not carry out corporate social responsibility are subject to administrative sanctions in the form of written warnings and other forms of sanctions in accordance with statutory regulations (Andrew Shandy Utama and Rizana, 2018: 90). Regulations regarding other forms of sanctions refer to Article 34 of Law Number 25 Year 2007 concerning Investment, namely limitation of business activities, freezing of business activities, and revocation of business activities.

If PT Asia Forestama Raya does not carry out corporate social responsibility to the community, the company will be subjected to administrative sanctions by the Pekanbaru City Government in the form of written warnings, restrictions on business activities, freezing of business activities, or the revocation of PT Asia Forestama Raya's business activities.

\section{CONCLUSION}

PT Asia Forestama Raya does not carry out corporate social responsibility in the Rumbai Pesisir District of Pekanbaru City, especially programs related community economy empowerment.

The obstacles in its implementation can be observed from three aspects: from the company side, the financial condition of PT Asia Forestama Raya is currently in an unstable condition so the community economic empowerment program had not been carried out for three years; from the community side, there is a lack of public knowledge regarding Regional Regulation of Riau Province Number 6 Year 2012 concerning Corporate Social Responsibility in Riau Province; from the government side, there is no adequate supervision of the implementation of corporate social responsibility by PT Asia Forestama Raya.

Efforts to overcome these obstacles are based on Article 32 of Regional Regulation of Riau Province No. 6 of 2012 concerning Corporate Social Responsibility in Riau Province, emphasizing that if PT Asia Forestama Raya does not implement corporate social responsibility for community economic empowerment in the Rumbai Pesisir District of Pekanbaru City, then the company may be subject to administrative sanctions in the form of a written warning from the Pekanbaru City Government as well as restrictions on business activities, freezing of business licenses, up to revocation of business licenses.

\section{RECOMMENDATIONS}

PT Asia Forestama Raya should implement corporate social responsibility to community economic empowerment in the Rumbai Pesisir District of Pekanbaru City, pursuant to what is stipulated in Article 10 and Article 11 of Regional Regulation of Riau Province Number 6 of 2012 concerning Corporate Social Responsibility in Riau Province.

PT Asia Forestama Raya should submit an official report to the Rumbai Pesisir District Head regarding corporate social responsibility programs that will be carried out or have been carried out in the Rumbai Pesisir District of Pekanbaru City, in accordance with what is regulated in Article 28 of Regional Regulation of Riau Province Number 6 of 2012 concerning Corporate Social Responsibility in Riau Province. 
The Government of the Rumbai Pesisir District of Pekanbaru City should work closely with PT Asia Forestama Raya and the Faculty of Law of Lancang Kuning University to provide legal counsel to the public regarding Law Number 25 of 2007 concerning Investment, Law Number 40 of 2007 concerning Limited Liability Companies, as well as Regional Regulation of Riau Province No. 6 of 2012 concerning Corporate Social Responsibility in Riau Province to avoid misunderstandings between the company and the community.

\section{REFERENCES}

1. Amiruddin and Zainal Asikin, 2012, Pengantar Metode Penelitian Hukum, Jakarta, Rajawali Pers.

2. Fahmi, 2015, Pergeseran Tanggung Jawab Sosial Perseroan; Dari Tanggung Jawab Moral ke Tanggung Jawab Hukum, Yogyakarta, FH UII Press.

3. Habib Adjie, 2008, Status Badan Hukum, Prinsip-prinsip, and Tanggung Jawab Sosial Perseroan Terbatas, Bandung, Mandar Maju.

4. Hendrik Budi Untung, 2009, Corporate Social Responsibility, Jakarta, Sinar Grafika.

5. Ridwan Khairandy, 2009, Perseroan Terbatas: Doktrin, Peraturan Perundang-undangan, and Yurisprudensi, Yogyakarta, Kreasi Total Media.

6. Soerjono Soekanto, 2007, Pengantar Penelitian Hukum, Jakarta, UI Press.

7. Andrew Shandy Utama and Rizana, Implementasi Corporate Social Responsibility PT Riau Crumb Rubber Factory terhadap Masyarakat Kelurahan Sri Meranti Kota Pekanbaru, Jurnal Novelty, Vol. 8 No. 2, 2017, pp. 173-186.

8. Andrew Shandy Utama and Rizana, Upaya Hukum Masyarakat Kecamatan Rumbai Pekanbaru dalam Pemenuhan Hak Masyarakat Melalui Program Corporate Social Responsibility (CSR), Jurnal Melayunesia Law, Vol. 2 No. 1, 2018, pp. 79-93.

9. Budi Santoso, International CSR Standards dari Sudut Pandang Hukum Internasional, Jurnal Respublica, Vol. 9 No. 2, 2010, pp. 211-222.

10. Fahmi, Tanggung Jawab Sosial Perusahaan; dari Tanggung Jawab Moral Menuju Tanggung Jawab Hukum yang Berkeadilan Sosial, Jurnal Respublica, Vol. 11 No. 1, 2011, pp. 16-31.

11. Ferdi, Aspek Hukum Internasional dalam Pengaturan Tanggung Jawab Sosial Perusahaan (Corporate Social Responsibility), Jurnal Respublica, Vol. 8 No. 2, 2009, pp. 224-231.

12. Firdaus, Corporate Social Responsibility; Transformasi Moral ke dalam Hukum dalam Membangun Kesejahteraan Masyarakat, Jurnal IImu Hukum, Ed. 1 No. 1, 2010, pp. 1630.

13. Firdaus, Corporate Social Responsibility dalam Hak Asasi Manusia; Studi terhadap Pemenuhan Hak Ekonomi Sosial Masyarakat Lokal oleh Perusahaan Perkebunan Kelapa Sawit, Jurnal Respublica, Vol. 11 No. 1, 2011, Pp. 1-15.

14. Lelisari Siregar and Rahdian Ihsan, Penerapan Ketentuan Corporate Social Responsibility (CSR) pada Perusahaan Swasta, Jurnal lus, Vol. I No. 2, 2013, pp. 220 234.

15. Pujiyono, Jamal Wiwoho, and Triyanto, Model Pertanggungjawaban Hukum Pelaksanaan Corporate Social Responsibility (CSR) untuk Meningkatkan Kesejahteraan Masyarakat, Jurnal Yustisia, Vol. 5 No. 1, 2016, pp. 41-51.

16. Sefriani and Sri Wartini, Model Kebijakan Hukum Tanggung Jawab Sosial Perusahaan di Indonesia, Jurnal lus Quia lustum, Vol. 24 No. 2, 2017, pp. 1-28.

17. Sentosa Sembiring, Tanggung Jawab Sosial and Lingkungan (Corporate Social and Environment Responsibilities) dalam Perspektif Hukum Perusahaan, Jurnal Yustisia, Ed. 77, 2009, pp. 66-72.

18. Siska Sukmawaty, Membangun Daerah Melalui Kebijakan Tanggung Jawab Sosial Perusahaan, Jurnal Selat, Vol. 4 No. 2, 2017, pp. 205-218.

19. Siregar, Inova Fitri, And Dini Onasis. "Penilaian Etis Manager Terhadap Konflik Kepentingan Atas Aktivitas Corporate Social Responsibility." Jurnal Daya Saing 4.1 (2018): 30-35. 
20. Suparman, Corporate Social Responsibility; Bentuk Tanggung Jawab Sosial and Kepedulian Perusahaan dengan Masyarakat, Jurnal Interaksi, Vol. II No. 2, 2013, pp. 6981.

21. Yayan Sopyan, Corporate Social Responsibility (CSR) sebagai Implementasi Fikih Sosial untuk Pemberdayaan Masyarakat, Jurnal Ahkam, Vol. XIV No. 1, 2014, pp. 53-62.

22. Yetti, Tanggung Jawab Perusahaan terhadap Sosial and Lingkungan Berdasarkan Undang-Undang Nomor 40 Tahun 2007 tentang Perseroan Terbatas, Jurnal Respublica, Vol. 7 No. 1, 2007, pp. 113-118.

23. Yetti, Implikasi Corporate Social Responsibility terhadap Aplikasi Undang-Undang Nomor 5 Tahun 1999, Jurnal Respublica, Vol. 11 No. 1, 2011, pp. 32-45.

24. Zulfikar Jayakusuma, Tanggung Jawab Sosial Perusahaan Transnasional Pertambangan Minyak terhadap Masyarakat Lokal (Perspektif Hak Asasi Manusia), Jurnal Respublica, Vol. 7 No. 1, 2007, pp. 101-115.

25. Law Number 25 of 2007 concerning Investment.

26. Law Number 40 of 2007 concerning Limited Companies.

27. Regional Regulation of Riau Province Number 6 of 2012 concerning Corporate Social Responsibility in Riau Province. 